\title{
Determinants of Online Local Budget Transparency in Croatia and Slovenia ${ }^{1}$
}

\author{
Katarina Ott, Mihaela Bronić, Branko Stanić \\ Institute of Public Finance, Croatia \\ kott@ijf.hr, mihaela@ijf.hr, branko.stanic@ijf.hr \\ https://orcid.org/0000-0003-2242-4181 \\ https://orcid.org/0000-0002-0863-2040 \\ https://orcid.org/0000-0002-8746-6764 \\ Maja Klun, Jože Benčina \\ Faculty of Public Administration, University of Ljubljana, Slovenia \\ maja.klun@fu.uni-lj.si, joze.bencina@fu.uni-lj.si \\ https://orcid.org/0000-0002-1025-9134 \\ https://orcid.org/0000-0002-3676-6214
}

Received: 11. 8. 2019

Accepted: 24. 9. 2019

\section{ABSTRACT}

As a part of the public governance, transparency started to come forward during the New Public Management reforms, mostly for the evaluation of public sector efficiency. This article focuses on online local budget transparency (OLBT) in two neighbouring countries - Croatia and Slovenia. The article is pioneering in a comparative study of the determinants of budget transparency in the Central and Eastern European (CEE) countries, based on a unique database and measure of transparency. The article tests the determinants of OLBT that reflect the accountability of local authorities and a cornerstone for public participation in the budget process. The following methodology was applied: using a data set of 768 Slovenian and Croatian local governments over the 2015-2017 period and testing it against several financial and socio-economic variables, and a random effects panel logistic regression, separately for Croatia, Slovenia, and a pooled sample. The results indicate that greater size of the population, higher administrative capacity and lower unemployment rate in individual local governments significantly contribute to higher levels of OLBT. This study demonstrates the possibility of developing a standardised measure of local budget transparency and using it to investigate the reasons for different levels of transparency in the two - and potentially other - CEE countries. The results of this and similar studies can serve as

1 This work was supported by the Croatian Science Foundation (CSF) under Grant (IP-2014-093008) and by the Slovenian Research Agency (SRA) under projects (ID P5-0093 and J5-8238). CSF also funded the work of doctoral student Branko Stanić. The opinions, findings, conclusions and recommendations are those of the authors and do not necessarily reflect the views of the CSF and SRA. 
a basis for establishing cohesive local budget transparency policies for different countries and creating a combination of policy instruments to enhance transparency.

Keywords: local self-government, online local budget transparency, panel data analysis, Croatia, Slovenia

JEL: $H 70, H 83$

\section{Introduction}

Traditional public administration theories were not too preoccupied with transparency. However, when economic - especially managerial - ideas became popular, the new public management started to treat it as one of the tools for evaluating the efficiency and effectiveness of public services (Douglas and Meijer, 2016; Grimmelikhuijsen and Meijer, 2014). Usually connected with 'good governance', despite an extensive range of typologies (Lampropoulou and Oikonomou, 2018; Ongaro, 2009; Osborne, 2006), transparency has been determined to be one of the important principles in the new public management. According to the Strategy on Innovation and Good Governance at Local Level (Council of Europe, 2007) one of the principles of good democratic governance is 'Openness and Transparency, to ensure public access to information and facilitate understanding of how local public affairs are conducted'. In line with that, budget transparency (BT) and citizens' participation have also become to be considered critical elements for efficient public service delivery, government accountability and citizen trust, particularly at local government levels (e.g., OECD, 2017; Pina et al., 2010; Piotrowski and Van Ryzin, 2007).

Transparency is now being mentioned in the strategic documents of two neighbouring countries, Croatia and Slovenia, once constituent republics of the Socialist Federative Republic of Yugoslavia, as one of the principles of good governance and a necessary part of public administration reforms. This research, in line with this endeavour, focuses on online local budget transparency (OLBT) in the two states. Nevertheless, despite the same regulations applying, the levels of OLBT differ among local governments even within the individual countries. This article, then, investigates the determinants of OLBT while keeping in mind the various approaches in the existing literature (e.g., Caba Pérez et al., 2005; Gandía and Archidona, 2008; Gesuele and Metallo, 2017; Lowatcharin and Menifield, 2015), which show the heterogeneity and dependency of different determinants (Alcaide-Muñoz and Rodríguez Bolivar, 2015; Alcaide Muñoz et al., 2017). It has been proved that information and communication technologies (ICT) can improve openness and transparency by using web-based tools to provide better information (Wong and Welch, 2004). However, there is still a relatively small number of studies focusing on online budget transparency (e.g., Caba-Pérez et al., 2008; García-Tabuyo et al., 2016; Laswad et al., 2005; Lowatcharin and Menifield, 2015; Sedmihradská, 2015; Pintea et al., 2013; Pintea, 2014; Styles and Tennyson, 2007). 
To establish the determinants of OLBT, it was first necessary to measure it, i.e. to find out how many of five local budget documents that have been identified as crucially important (the year-end report, mid-year report, budget proposal, enacted budget and citizens' budget) 212 Slovenian municipalities and 126 cities and 428 municipalities in Croatia are publishing on their web sites. After that, in order to test the influence of independent variables on the inclination of local government units (LGUs) to publish key local budget documents, a random effects panel logistic regression for 2015-2017 period is used, separately for Croatian and Slovenian LGUs and then for the whole sample. The analysis shows that higher populations, higher administrative capacities and lower unemployment rates in an LGU contribute significantly to greater OLBT. These results are in line with those previously obtained by other researchers. Although the article has some limitations, outlined below, the findings might add to the existing literature, as research of this kind and with such comprehensive data collection is relatively rare in Central and Eastern Europe. It might be significant that similar determinants have similar influences on the LBT in two relatively young, ex-socialist countries to those that have been observed in more established, older public administrations.

The following section presents the theoretical and research background and development of hypotheses for the determinants of OLBT, the third describes the data and the research methodology, the fourth offers results and analysis, and the fifth concludes and summarizes observations and recommendations.

\section{Literature review}

Definitions of transparency, as well as of budget transparency, can be broader or narrower (Lowatcharin and Menifield, 2015). Fiscal and budget transparency are often used as synonyms (Alt et al, 2006; OECD, 2017), but fiscal transparency is a wider concept than budget transparency (Kopits and Craig, 1998).

There are various theoretical approaches to transparency. The principal-agent theory usually describes the information gap between citizens and the government as a major obstacle to effective and constructive public participation. Because of the information gap, the agent has an advantage in persuading citizens (the principal) that everything is done in their best interests (Groenendijk, 1997). Some authors stress the importance of transparency in diminishing the information gap (e.g. Ferejohn, 1999; Laswad et al., 2005; Zimmerman, 1977; Banker and Patton, 1987). According to the legitimacy theory (Suchman, 1995; Patten, 1992; Deegan, 2002; De Araújo and Tejedo-Romero, 2016; Alcaide Muñoz et al., 2017), government uses transparency to promote its legitimacy and reputation. Alesina and Perotti (1996) elaborated the fiscal illusion theory, which draws on the perception that the citizen (taxpayer) is not capable of evaluating the cost of public programmes. Fiscal transparency helps to overcome that problem by giving citizens more information, and, therefore decreasing the illusion produced by the underestimated costs and overestimated benefits of public spending. All these theories are in line with the notion of transparency as a principle of good governance. However, 
it is questionable whether it is enough to establish a principle and to make administrative reforms towards good governance. Hence, the motivation for testing some of the variables that might determine the budget transparency, in this case, OLBT.

\subsection{Development of hypotheses}

Motivated by the detailed literature review presented in Stanić (2018), and using the theories explained above, five hypotheses were developed, positing residents' income per capita (p.c.), population size, fiscal capacity, administrative capacity and unemployment, the most often used socio-demographic, fiscal and political variables, as determining factors in the achievement of budget transparency, or the reverse.

\subsubsection{Residents' income p.c.}

According to several authors, residents with higher incomes usually have greater Internet access and experience (Styles and Tennyson, 2007). They are also more demanding in respect of additional public services (Giroux and McLelland, 2003; Piotrowski and Van Ryzin, 2007) and information (Piotrowski and Van Ryzin, 2007). In some research, residents' income had no significant correlation (Guillamón et al., 2011), while other studies (Lowatcharin and Menifield, 2015) showed a significant positive correlation between residents' income p.c. and government transparency. Ott et al. (2018) and Ott et al. (2019) in the analysis of determinants of OLBT for Croatia also showed that residents' income p.c. positively affects OLBT. Therefore, we assumed that:

H1. The higher the residents' income p.c., the greater the OLBT.

\subsubsection{Population}

Larger LGUs are more often pressured to provide information (Moon and Norris, 2005; Serrano-Cinca et al., 2009), and usually have higher revenues and an IT department (Caba-Pérez et al., 2008). Serrano-Cinca et al. (2009) argue that conflicts of interest are more likely in more populated areas and the advantage of disclosing information is correspondingly greater.

Several authors found a positive and statistically significant relationship between population and data availability (Guillamón et al., 2011; del Sol, 2013; Lowatcharin and Menifield, 2015; De Araújo \& Tejedo-Romero, 2016; Ott et al., 2018; Ott et al., 2019; Benčina et al., 2019). Therefore, we assumed that:

H2. As the population rises, the level of OLBT increases.

\subsubsection{Fiscal capacity}

Fiscal capacity (FC) is the ability to raise revenues (Martinez-Vazquez and Timofeev, 2008). Some other authors use the concept of financial autonomy (Tavares and da Cruz, 2014). Residents' income p.c. is linked to FC, since it implies higher tax and nontax revenues. Alcaide Muñoz et al. (2017) argue that 
larger cities are more likely to provide information, since they can afford it and that higher $\mathrm{FC}$ is followed by higher pressure from their citizens to justify the use of resources, so agents are keen to show that they act responsibly.

There are various proxies for the FC. Guillamón et al. (2011) used p.c. tax revenues and obtained a positive correlation with financial transparency. Laswad et al. (2005) used general revenues minus intergovernmental transfers, finding no significant correlation with voluntary Internet financial reporting. This study uses operating revenues (excluding grants) as a proxy for FC the variable previously used in Ott et al. (2019) in Croatia that proved that it positively affects OLBT. Therefore, we assumed that:

H3. The higher the fiscal capacity in an LGU, the greater its OLBT.

\subsubsection{Administrative capacity}

The administrative capacity largely defines the ability to produce budget documents. Tavares and da Cruz (2014) show its influence associating it with a more professional organization and IT educated staff. This paper assumes that LGUs with a larger number of employees can more easily disclose more information.

The proxy for administrative capacity here is the natural logarithm of the annual average number of employees in LGU bodies (based on hours worked). This variable was previously used in Ott et al. (2019) in Croatia and it was proven that it positively affects OLBT. It assumes that LGUs with a larger number of employees have specialized staff able to devote additional time to OLBT. Therefore, we assumed that:

H4. The larger the labour force of an LGU, the greater the OLBT.

\subsubsection{Unemployment}

As explained in detail in Stanić (2018), it has been argued that lower economic development and the associated higher unemployment rates are damaging to civic engagement, i.e. the demand for greater opportunities to participate in the decision-making diminishes. Some studies have used unemployment as a proxy for an LGU's economic status and found that higher economic status (lower unemployment) positively affects the transparency in public administration (Piotrowski and van Ryzin, 2007). In accordance with these underpinnings, the results largely indicate that higher unemployment rates are detrimental to fiscal transparency (Caamaño-Alegre et al., 2013; De Araújo and Tejedo-Romero, 2016; del Sol, 2013; Tavares and da Cruz, 2014). Thus, the following hypothesis is proposed:

H5. The lower the unemployment, the greater the OLBT. 


\section{Data and methodology}

This section presents the number and types of LGUs in Croatia and Slovenia, their regulation of the local budget transparency, dependent variable and sample, included independent variables; and finally, the model specification.

\subsection{Local government and budget transparency in Croatia}

Croatia consists of 428 municipalities, 128 cities and 20 counties. According to the Budget Act and Act on the Right of Access to Information, they are all obliged to publish three budget documents - the enacted budget, the yearend report, and mid-year report - on their websites. For the additional two documents - budget proposal and citizen budget - there is no legal obligation, but only a recommendation from the Ministry of Finance. Therefore, in Croatia, three of the five key budget documents should be disclosed mandatorily and the other two voluntarily.

\subsection{Local government and budget transparency in Slovenia}

Slovenia is divided into 212 municipalities, 11of which have urban status. In accordance with the Public Finance Act, they are legally obliged to publish three key budget documents - budget proposal, enacted budget, and a yearend report. The publication of the remaining two documents - mid-year report and citizen budget - is not statutory obligation. However, since 2016, the Ministry of Public Administration has recommended the publication of all five key documents. Therefore, in Slovenia, it is mandatory to disclose three of the five key budget documents but only voluntary to disclose the other two.

\subsection{Dependent variable and sample}

The dependent variable is the Open Local Budget Index (OLBI) developed by Ott et al. (2015), as a count data index that shows the availability of five key local budget documents on an LGU's web site. It is calculated annually, e.g. OLBI 2017 includes year-end report 2016, mid-year report 2017, budget proposal, enacted budget and citizen budget 2018. The choice of these five budget documents is based on good international practices suggested by e.g. OECD (2002) and IBP (2016). 
Graph 1: Local governments' average annual budget transparency score

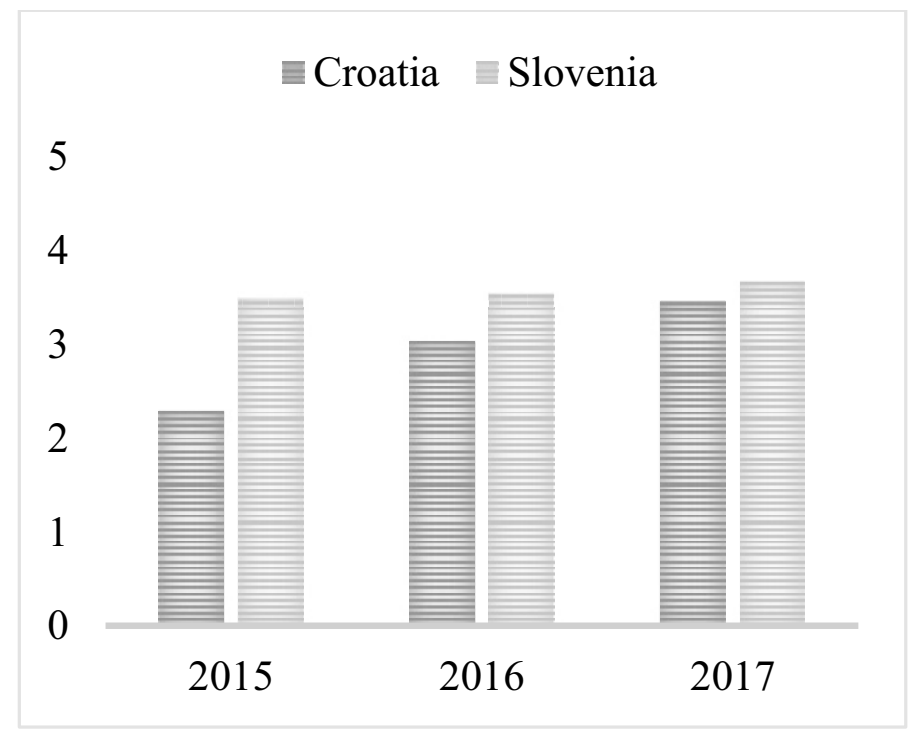

Source: Authors' calculations

Graph 1 shows that the average OLBT in Croatia and Slovenia - measured by how many key budget documents are published on their websites - is constantly improving. While there was a marked difference in 2015, when Slovenia had far greater average OLBT (3.49 vs. 2.28), in 2017, the Croatian average OLBT almost caught up with the Slovenian average (3.46 vs. 3.67).

Since in both Croatia and Slovenia three of the five key budget documents are mandatory, and two voluntary, for the purpose of this paper OLBI is transformed into a binary variable. It takes the value of 1 if the LGU has published four or five key budget documents, denoting a transparent LGU, which, in addition to being a statutory obligation, publishes a minimum of one voluntary budget document; and 0 otherwise. In other words, in investigating the determinants of OLBT, this study considers both mandatory and voluntary disclosure. 


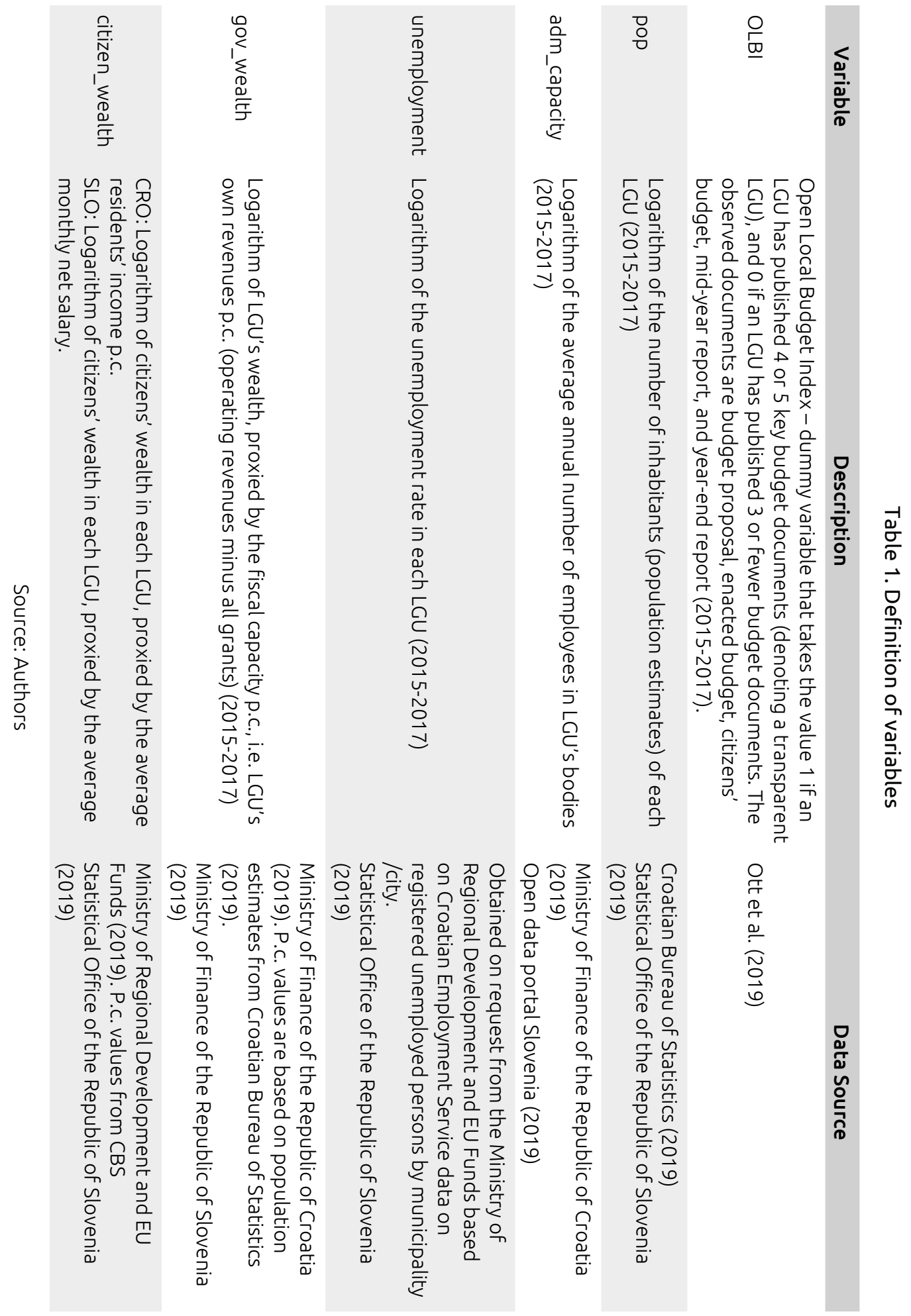


The sample includes 768 LGUs - in Croatia 428 municipalities and 128 cities, and in Slovenia 212 municipalities.

\subsection{Independent variables}

Some possibly interesting and influential independent variables (e.g. Internet access) were not investigated, as it was not possible to obtain comparable data. Independent variables include internal forces and external pressures that could, in accordance with the above-mentioned transparency theories, explain what determines OLBT. The internal force (feature) variables in this article are the LGU's administrative capacity (adm_capacity), proxied by the average annual number of its employees and the LGU's wealth (gov_wealth), proxied by its p.c. fiscal capacity (operating revenues other than grants). The external pressure variables are: the LGU's size, i.e. the number of inhabitants $(p o p)$, describing the demand-side capacity; unemployment rate (unemployment), as a proxy for the economic situation in the LGU; and citizens' wealth (citizen_wealth), proxied by the income p.c. in Croatian, and net salary in Slovenian LGUs (Table 1).

In order to test the influence of independent variables on the inclination of the LGU to publish key local budget documents, a panel logistic regression for the 2015-2017 period is used, separately for Croatian and Slovenian LGUs, as well as for the total sample.

The model specification is as follows:

$$
\begin{aligned}
P\left(y_{i t}=1\right)=\mu_{0} & +\mu_{1} \text { pop }_{i t}+\mu_{2} \text { adm_capacity }_{i t}+\mu_{3} \text { unemployment }_{i t}+\mu_{4} \text { gov_wealth }_{i t} \\
& +\mu_{5} \text { citizen_wealth }_{i t}+\varepsilon_{i t}, i=1, \ldots N ; t=1, \ldots T
\end{aligned}
$$

where $P$ is the probability that an LGU will achieve higher budget transparency levels (publishing 4 or 5 budget documents online, i.e. at least one voluntary document); $\mu_{0}$ is a constant term; $i$ denotes LGU; $t$ is time; $\mu$ are the parameters to be estimated; $\varepsilon$ is the error term. Included independent variables are defined above.

\section{Results and analysis}

Table 2 shows the descriptive statistics - in panel A for the continuous (explanatory) variables and in panel B for the discrete (dependent) variable. The sub-samples of Croatian and Slovenian LGUs show significant differences in certain variables that could have an important impact on OLBT. In particular, Croatian LGUs have a much higher average value for the unemployment rate than the Slovenian do. Regarding the gov_wealth variable, proxied by fiscal capacity p.c. (operating revenues other than grants), Slovenian LGUs have on average more than double the amount of Croatian LGUs (820 vs. 372 EUR p.c.). 


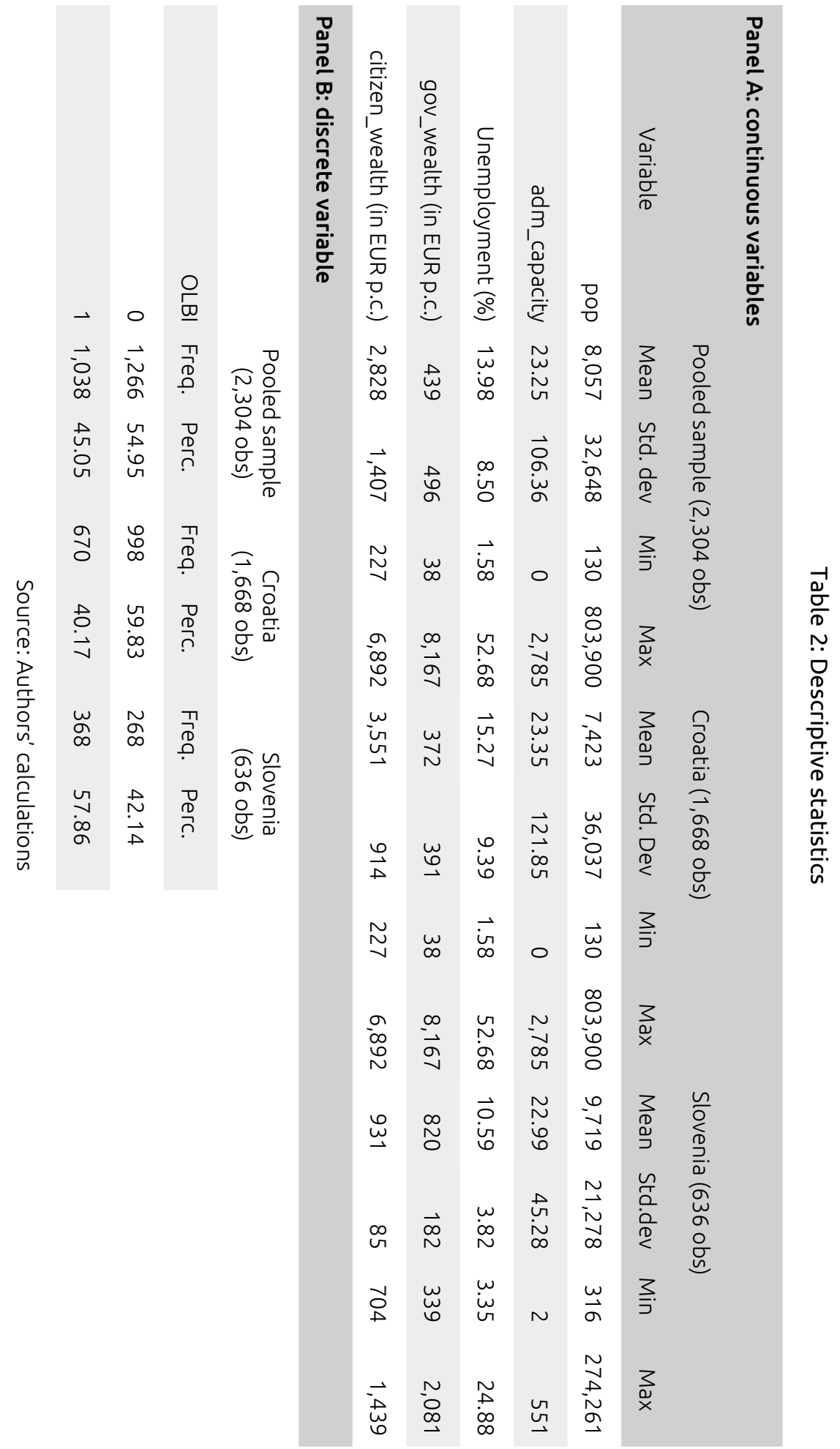


Before estimating the regression equation, the relationship among covariates is explored. Accordingly, to test the presence of multicollinearity, tables A1, A2 and A3 in Appendix show correlation matrices for Croatia, Slovenia, and the pooled sample, respectively. If the correlation values among covariates are 0.75 or above, there is a multicollinearity issue (Gesuele et al., 2017).

Table A1 shows that the dependent variable $O L B$ I has a statistically significant, linear and expected relationship with the independent variables. It also suggests a multicollinearity problem, i.e. a high correlation between pop and adm_capacity (0.78), which is taken into account in estimating the regression equation, so two models are estimated for the Croatian sample.

With respect to the Slovenian sample, the dependent variable $O L B /$ has statistically significant, linear and expected relationships with all the independent variables, with the exception of gov_wealth (nonsignificant relationship) and citizen_wealth (negative and nonsignificant relationship) (Table A2). There is also a multicollinearity problem between variable pop and adm_capacity (0.91), which is taken into account in a regression analysis.

Regarding pooled sample, the dependent variable $O L B /$ has statistically significant, linear and expected relationships with all the independent variables, with the exception of citizen_wealth (a negative, although barely significant, relationship) (Table A3). A multicollinearity issue suggests a high correlation between pop and adm_capacity (0.81), which is taken into account when estimating the regression equation.

Since the data indicates larger between than within effects, a random effects panel logistic regression is estimated, which allows for modelling heterogeneity across units. The random effects model considers both within and between group variations. 


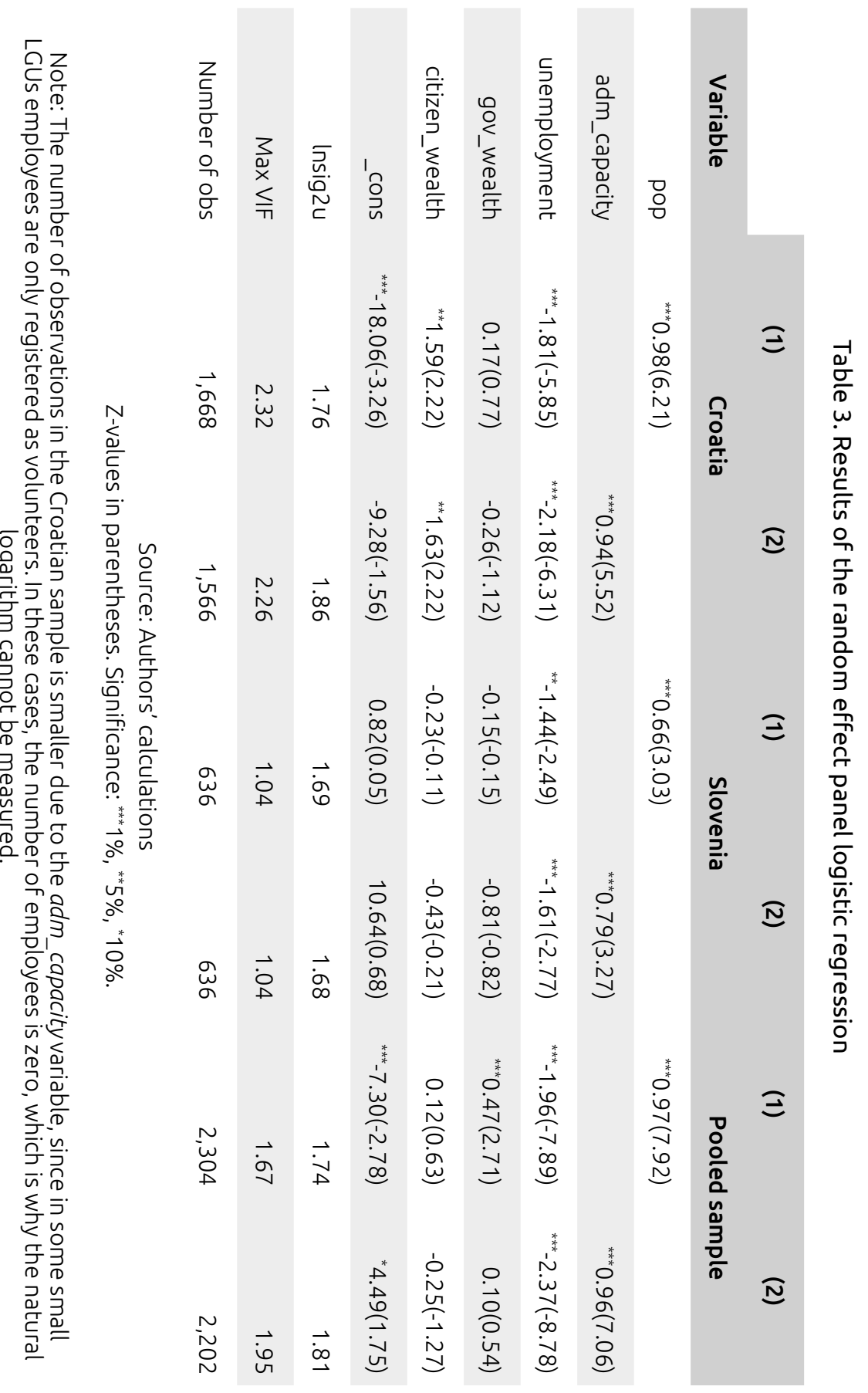


Table 3 shows that higher population, higher administrative capacity and lower unemployment rate in the LGU significantly contribute to greater OLBT. These results are consistent for all three samples and in all the models estimated. Several authors also found that population positively affects local governments' budget/fiscal transparency (De Araújo and Tejedo-Romero, 2016; del Sol, 2013; Guillamón et al., 2011; Styles and Tennyson, 2007; Ott et al., 2018; Ott et al., 2019, Benčina et al., 2019). Explanations are usually given in two directions. First, LGUs with a larger population usually manage more public resources and are therefore faced with greater pressures to account for them (demand-side pressures). Second, larger LGUs can employ more human and material resources and establish an IT division that will also engage in transparency and accountability issues.

Manoharan (2013) found a positive relationship between the number of IT employees and website adoption. These findings are in line with the results obtained in this study, i.e. the greater the number of employees in LGUs (the greater the administrative capacity) the greater their OLBT; as confirmed in the previous study of Croatian LGUs (Ott et al., 2019). LGUs with higher administrative capacities have greater opportunities to produce and publish budget documents in a timely manner; and they often have better educated and more professional staff than smaller LGUs (Tavares and da Cruz, 2017).

The results also show that higher unemployment reduces budget transparen$c y$; and this relationship is consistent for all - Croatian, Slovenian, and pooled sample - and in all estimated models. These findings support previous research by (Caamaño-Alegre et al., 2013; De Araújo and Tejedo-Romero, 2016; del Sol, 2013), concluding that a worse economic situation in the LGU (higher unemployment) hinders greater accountability and transparency in local authorities.

Results for variable gov_wealth-representing the fiscal capacity of the LGU p.C. - are insignificant, except in the pooled sample in the model with population included, where the results are positive and significant. The same results were previously obtained for Croatia by Ott et al. (2019). This result suggests that higher LGU own revenues (fiscal capacity) enable more space, time, and ability to be more transparent and accountable to citizens (Gandía et al., 2016; Laswad et al., 2005). However, results for this variable are mostly nonsignificant, indicating the need for further research to obtain results that are more robust.

For the the citizen_wealth variable, the results are positive and significant only in the Croatian sample as previously proved in Ott et al., (2018) and Ott et al. (2019). This indication of Croatian LGUs with a higher average income p.c. being more likely to publish four or five budget documents than units with smaller citizen_wealth is in line with several previous researches (Lowatcharin and Menifield, 2015; Styles and Tennyson, 2007).

\section{Conclusion}

This research focused on the determinants of OLBT in two neighbouring countries - Slovenia and Croatia. Given the common contextual background and a 
similar pace of democratization - e.g. both countries are EU members - one would expect them to have similar levels of OLBT. To see whether this is so, it was first necessary to measure their OLBT levels, i.e. to find out how many of five key local budget documents (the year-end report, mid-year report, budget proposal, enacted budget and citizens' budget) the 212 municipalities in Slovenia and the 128 cities and the 428 municipalities in Croatia publish on their web sites. The measurements showed that the average OLBT in Croatia and Slovenia - measured by how many of the five budget documents are published on their respective websites - although constantly improving are neither satisfactory, nor similar. While there was a marked difference in 2015, when Slovenia had far greater average OLBT (3.49 vs. 2.28), in 2017, the Croatian average OLBT had almost caught up with the Slovenian average (3.46 vs. 3.67).

After establishing the OLBT levels in the two countries, in order to test the influence of various independent variables on the inclination of an LGU to publish key local budget documents, a random effects panel logistic regression for the 2015-2017 period is used, separately for Croatian and Slovenian LGUs and then for the whole sample. The analysis shows that higher population, higher administrative capacity and lower unemployment rate in the LGU significantly contribute to greater OLBT. The results are in line with theoretical transparency underpinnings and several research efforts, indicating that greater population size and higher employment (as demand-side factors), enable citizens to put more pressure on local government and, through various channels, to scrutinize budget information and demand expansions. On the other hand, the greater administrative capacity of a local government (as a supply-side factor), reflects its internal capacity to engage in budget transparency and accountability initiatives. However our hypotheses that residents' income p.c. and LGUs' fiscal capacity significantly positively contribute to greater OLBT can only be partly accepted - they had expected positive sign, but were not significant in all models.

While Slovenian local governments showed a higher OLBT from the outset, Croatian local governments have only reached this level in the last few years. In part, this can be attributed to Slovenia's earlier reform of public administration and the introduction of e-governance, in line with earlier accession to EU and EU requirements. Although OLBT is not a comprehensive measure of budget transparency, it is based on good budget transparency practices, thus providing a basis for greater levels of budget transparency, accountability and public participation. Thus the results indicate that more efforts are needed from both Croatian and Slovenian local governments, as many of them do not even meet the legal requirements of budgetary transparency.

Studies of local budget transparency are of great importance, since they can influence decision making at central government levels, and their results can also trigger, usually through media coverage, positive peer pressure among local governments. Our research shows that legal regulation is obviously a necessary but not a sufficient condition for improving local budget transpar- 
ency in these two countries, and that capacity of local governments, population size and unemployment rate are the main triggers for improvement. This article has two main limitations. First, one important feature of budget transparency, the quality of the documents, was not observed; secondly, some variables often used by other researchers (e.g. Internet access) were not investigated. For the former, it would simply be impossible each year to control the quality of five budget documents in 768 LGUs over three years and for the latter, comparable data are missing.

Despite these limitations, the findings could well make a useful addition to the existing body of literature, since the study, with its comprehensive collection of data, is quite rare in Central and Eastern Europe. It might also be significant that, despite the differences in the economic and political environments of these two countries, in the observed period there are nevertheless some common determinants of LBT. 
Katarina Ott, Mihaela Bronić, Branko Stanić, Maja Klun, Jože Benčina

\section{Appendix}

Table A1. Correlation matrix for the Croatian sample

\begin{tabular}{|c|c|c|c|c|c|c|}
\hline & OLBI & pop & $\underset{\text { capacity }}{\text { adm_- }}$ & $\begin{array}{l}\text { unempl } \\
\text { oyment }\end{array}$ & $\underset{\text { wealth }}{\text { gov }_{-}}$ & $\begin{array}{l}\text { citizen_- } \\
\text { wealth }\end{array}$ \\
\hline OLBI & 1.000 & & & & & \\
\hline pop & 0.276 & 1.000 & & & & \\
\hline adm_capacity & 0.220 & 0.779 & 1.000 & & & \\
\hline unemployment & -0.249 & -0.041 & 0.094 & 1.000 & & \\
\hline gov_wealth & 0.213 & 0.110 & 0.314 & -0.475 & 1.000 & \\
\hline citizen_wealth & 0.288 & 0.298 & 0.285 & -0.624 & 0.600 & 1.000 \\
\hline
\end{tabular}

Table A2. Correlation matrix for the Slovenian sample

\begin{tabular}{|rrrrrrr|}
\hline OLBI & 1.000 & & & & & \\
pop & 0.172 & 1.000 & & & & \\
capacity & $\begin{array}{c}\text { unempl } \\
\text { oyment }\end{array}$ & $\begin{array}{c}\text { gov_- } \\
\text { wealth }\end{array}$ & $\begin{array}{c}\text { citizen_ } \\
\text { wealth }\end{array}$ \\
\hline adm_capacity & 0.175 & 0.909 & 1.000 & & & \\
\hline unemployment & -0.085 & -0.017 & 0.039 & 1.000 & & \\
\hline gov_wealth & 0.004 & -0.111 & 0.096 & -0.171 & 1.000 & \\
\hline citizen_wealth & -0.030 & -0.065 & -0.035 & -0.091 & 0.037 & 1.000
\end{tabular}

Source: Authors' calculations

Table A3. Correlation matrix for the pooled sample

\begin{tabular}{|c|c|c|c|c|c|c|}
\hline & OLBI & pop & $\begin{array}{l}\text { adm_apacity } \\
\text { cap }\end{array}$ & $\begin{array}{l}\text { unempl } \\
\text { oyment }\end{array}$ & $\underset{\text { wealth }}{\text { gov }_{-}}$ & $\begin{array}{l}\text { citizen_- } \\
\text { wealth }\end{array}$ \\
\hline OLBI & 1.000 & & & & & \\
\hline Pop & 0.270 & 1.000 & & & & \\
\hline adm_capacity & 0.218 & 0.811 & 1.000 & & & \\
\hline Unemployment & -0.234 & -0.071 & 0.066 & 1.000 & & \\
\hline gov_wealth & 0.231 & 0.195 & 0.273 & -0.455 & 1.000 & \\
\hline citizen_wealth & -0.052 & -0.108 & 0.004 & -0.061 & -0.402 & 1.000 \\
\hline
\end{tabular}




\section{References}

Act on the Right of Access to Information. Zakon o pravu na pristup informacijama. Pročišćeni tekst zakona. NN 25/13, 85/15 (2015). At <https:// www.zakon.hr/z/126/Zakon-o-pravu-na-pristup-informacijama>, accessed 14 May 2019.

Alcaide Muñoz, L., Rodríguez Bolívar, M. P. and López Hernández, A. M. (2017). Transparency in governments: a meta-analytic review of incentives for digital versus hard-copy public financial disclosures. American Review of Public Administration, 47(5), pp. 550-573.

Alcaide-Muñoz, L. and Rodríguez Bolívar, M. P. (2015). Determining factors of transparency and accountability in local governments: a meta-analytic study. Lex Localis - Journal of Local Self-Government, 13(2), pp. 129-160.

Alesina, A. and Perotti, R. (1996). Fiscal Discipline and the Budget Process. The American Economic Review, 86(2), 401-407.

Alt, J. E., Lassen, D. D. and Rose, S. (2006). The causes of fiscal transparency: evidence from the US states. IMF Staff Papers, pp. 30-57.

Andreula, N., Chong, A. and Guillén, J. (2009). Institutional quality and fiscal transparency. IDB working paper series No. IDB-WP-125, (December), 32. At <http://papers.ssrn.com/sol3/papers.cfm?abstract_id=1817228>, accessed 4 May 2019.

Banker, R. D. and Patton, J. M. (1987). Analytical agency theory and municipal accounting: an introduction and an application. Research in Governmental and Nonprofit Accounting, 3(Part B), pp. 29-50.

Benčina, J., Klun, M. and Umek, L. (2019). Analysis of the local budget transparency index in the last three years: the case of Slovenia. Public finance Quarterly- forthcoming.

Budget Act. Zakon o proračunu. NN 87/08, 136/12, 15/15 (2015). At <https:// www.zakon.hr/z/283/Zakon-o-prora\%C4\%8Dunu>, accessed 16 June 2019.

Caamaño-Alegre, J., Lago-Peñas, S., Reyes-Santias, F. and Santiago-Boubeta, A. (2013). Budget transparency in local governments: an empirical analysis. Local Government Studies, 39(2), pp. 182-207.

Caba-Pérez, C., López Hernández, A. M. and Pedro Rodríguez Bolívar, M. (2005). Citizens' access to on-line governmental financial information: practices in the European Union countries. Government Information Quarterly, 22(2), pp. 258-276.

Caba-Pérez, C., Rodríguez Bolívar, M. P. and López Hernández, A. M. (2008). e-Government process and initiatives for online public financial information. Online Information Review, 32(3), pp. 379-400.

Council of Europe (2007). Extract from the Valencia Declaration 15th Conference of European Ministers responsible for local and regional government (Valencia, Spain, 15-16 October 2007). At <https://rm.coe.int/1680701699>, accessed 10 July 2019.

Croatian Bureau of Statistics (CBS) (2019). At <https://www.dzs.hr/Hrv_Eng/ Pokazatelji/Gradovi\%20u\%20statistici.xlsx>, accessed 16 June $201 \overline{9}$.

Croatian Regulatory Authority for Network Industries (HAKOM) (2018). Access to the Internet (2014-2017).

De Araújo, J. F. F. E. and Tejedo-Romero, F. (2018). Does gender equality affect municipal transparency: the case of Spain. Public Performance and Management Review, 41(1), pp. 69-99. 
De Araújo, J. F. F. E. and Tejedo-Romero, F. (2016). Local government transparency index: determinants of municipalities' rankings. International Journal of Public Sector Management, 29(4), pp. 327-347.

Deegan, C. (2002). Introduction. Accounting, Auditing \& Accountability Journal, 15(3), pp. 282-311.

del Sol, D. A. (2013). The institutional, economic and social determinants of local government transparency. Journal of Economic Policy Reform, 16(1), pp. 90-107.

Douglas, S. and Meijer, A. (2016). Transparency and Public Value-Analyzing the Transparency Practices and Value Creation of Public Utilities. International Journal of Public Administration, 39(12), pp. 940-951.

Esteller-Moré, A. and Polo Otero, J. (2012). Fiscal transparency: does your local government respond? Public Management Review, 14(8), pp. 1153-1173.

Ferejohn, J. (1999). Accountability and authority: toward a theory of political accountability. In A. Przeworski, S.C. Stokes and B. Manin, eds., Democracy, accountability, and representation: Cambridge University Press, pp. 131-153.

Gandía, J. L. and Archidona, M. C. (2008). Determinants of web site information by Spanish city councils. Online Information Review, 32(1), pp. 35-57.

Gandía, J. L., Marrahí, L. and Huguet, D. (2016). Digital transparency and Web 2.0 in Spanish city councils. Government Information Quarterly, 33(1), pp. 28-39.

García-Tabuyo, M., Sáez-Martín, A. and Caba-Pérez, M. D. C. (2016). Mandatory versus voluntary disclosures. Information Development, 32(4), pp. 11991215.

Gesuele, B. and Metallo, C. (2017). Factors influencing mandatory and voluntary e-disclosure diffusion by municipalities. Lecture Notes in Information Systems and Organisation, 20(4), pp. 263-276.

Gesuele, B., Metallo, C. and Longobardi, S. (2017). The Determinants of E-Disclosure Attitude: Empirical Evidences from Italian and Spanish Municipalities. International Journal of Public Administration, 20(4), pp. 263-276.

Giroux, G. and McLelland, A. J. (2003). Governance structures and accounting at large municipalities. Journal of Accounting and Public Policy, 22(3), pp. 203-230.

Grimmelikhuijsen, S. G., and Meijer, A. J. (2014). Effects of transparency on the perceived trustworthiness of a government organization: Evidence from an online experiment. Journal of Public Administration Research and Theory, 24(1), pp. 137-157.

Groenendijk, N. (1997). A principal-agent model of corruption introduction: neo-institutional economics and corruption. Crime, Law and Social Change, 27(3/4), pp. 207-229.

Guillamón, M.-D., Bastida, F. and Benito, B. (2011). The determinants of local government's financial transparency. Local Government Studies, 37(4), pp. 391-406.

Ho, A. T.-K. (2002). Reinventing local governments and the E-government initiative. Public Administration Review, 62(4), pp. 434-444.

International Budget Partnership (2016) Guide to The Open Budget Questionnaire: An Explanation of the Questions and the Response Options, Washington. At <https://www.internationalbudget.org/wp-content/uploads/ open-budget-survey-2017-guide-and-questionnaire-english.pdf>, accessed 22 June 2019. 
Kopits, G. and Craig, J. (1998). Transparency in government operations. IMF Occasional Papers, No. 158, pp. 1-42.

Lampropoulou, M., and Oikonomou, G. (2018). Theoretical models of public administration and patterns of state reform in Greece. International Review of Administrative Sciences, 84(1), pp. 101-121.

Laswad, F., Fisher, R. and Oyelere, P. (2005). Determinants of voluntary Internet financial reporting by local government authorities. Journal of Accounting and Public Policy, 24(2), pp. 101-121.

Lowatcharin, G. and Menifield, C. E. (2015). Determinants of Internet-enabled transparency at the local level. State and Local Government Review, 47(2), pp. 102-115.

Ma, L. and Wu, J. (2011). What Drives Fiscal Transparency? Evidence from Provincial Governments in China, At <http://spaa.newark.rutgers.edu/home/ conferences/1stgctr/papers.html> , accessed 18 June 2019.

Manoharan, A. (2013). A Study of the Determinants of County E-Government in the United States. The American Review of Public Administration, 43(2), pp. 159-178.

Martinez-Vazquez, J. and Timofeev, A. (2008). Regional-local dimension of Russia's fiscal equalization. Journal of Comparative Economics, 36(1), pp. 157-176.

Meijer, A. J. (2012). The do it yourself state: The future of participatory democracy. Information Polity, 17(3-4), pp. 303-314.

Ministry of Finance of the Republic of Croatia (2019). Upute za izradu proračuna jedinica lokalne i područne (regionalne) samouprave za razdoblje 2013. 2015. At <http://www.mfin.hr/adminmax/docs/Upute za izradu proračuna JLP(R)S za razdoblje 2013.-2015..pdf> , accessed 3 June 2019.

Ministry of Finance of the Republic of Croatia (2019). Ostvarenje proračuna JLP(R)S za period 2012.-2016. At <http://www.mfin.hr/hr/ostvarenjeproracuna-jlprs-za-period-2014-2016>, accessed 15 May 2019.

Ministry of Finance of the Republic of Slovenia (2019). Local budget data. At <http://www.mf.gov.si/si/delovna_podrocja/lokalne_skupnosti/statistika/>, accessed 5 June 2019.

Ministry of Regional Development and European Union Funds (2018). Average residents income per capita for 2012-2016. Ministry of Regional Development and European Union Funds, Zagreb.

Moon, M. J. and Norris, D. F. (2005). Does managerial orientation matter? The adoption of reinventing government and e-government at the municipal level. Information Systems Journal, 15(1), pp. 43-60.

Ongaro, E. (2009). Public Management Reform and Modernization: Trajectories of Administrative Change in Italy, France, Greece, Portugal and Spain, Bocconi University and SDA Bocconi School of Management, Edward Elgar Publishing.

Open data Portal Slovenia (2019). Public sector data. At <https://podatki.gov. si/>, accessed 15 June 2019.

Organization for Economic Co-Operation and Development (2002). OECD Best Practices for Budget Transparency. OECD Journal on Budgeting, 1(3), pp. 7-14.

Organization for Economic Co-Operation and Development (2017). OECD Budget Transparency Toolkit: practical steps for supporting openness, integrity and accountability in Public Financial Management. OECD 
Publishing. At <https://www.oecd.org/governance/oecd-budget-

transparency-toolkit-9789264282070-en.htm>, accessed 17 June 2019.

Osborne, S.P. (2006). The new public governance? Public Management Review, 8(3), pp. 377-387.

Ott, K., Mačkić, V. and Bronić, M. (2018). Budget Transparency of Local Governments: The Political Economy of City and Municipality Budgets in Croatia. Društvena istraživanja, 27(4), pp. 629-647.

Ott, K., Mačkić, V., Bronić, M. and Stanić, B. (2019). Determinants of voluntary online local budget transparency: a case study from Croatia. Ekonomski pregled, 70(2), pp. 145-172.

Ott, K., Bronić, M. and Petrušić, M. (2015). Budget transparency in Croatian counties, cities and municipalities (November 2014 - March 2015).

Newsletter - an Occasional Publication of the Institute of Public Finance, pp. 1-13. At <http://www.ijf.hr/upload/files/file/ENG/newsletter/97.pdf>, accessed 27 June 2019.

Ott, K., Bronić, M., Petrušić, M. and Stanić, B. (2016). Budget transparency in Croatian counties, cities and municipalities (November 2015 - March 2016). Newsletter - an Occasional Publication of the Institute of Public Finance, 17(107), 1-14. At <http://www.ijf.hr/upload/files/file/ENG/newsletter/107. $p d f>$, accessed 28 June 2019.

Ott, K., Bronić, M., Petrušić, M. and Stanić, B. (2017). Budget transparency in Croatian counties, cities and municipalities (November 2016 - March 2017). Newsletter - an Occasional Publication of the Institute of Public Finance, 1-13. At <http://www.ijf.hr/upload/files/file/ENG/newsletter/112.pdf>, accessed 28 June 2019.

Patten, D. M. (1992). Intra-industry environmental disclosures in response to the Alaskan oil spill: a note on legitimacy theory. Accounting, Organizations and Society, 17(5), pp. 471-475.

Pina, V., Torres, L. and Royo, S. (2010). Is E-government leading to more accountable and transparent local governments? An overall view. Financial Accountability \& Management, 26(1), pp. 3-20.

Pintea, M.O. (2014). Transparency of local budgets in the Center Region of Romania. Review of Economic Studies and Research Virgil Madgearu, pp. 81-96.

Pintea, M.O., Achim, S. A. and Lacătuş, V. (2013). Transparency of local budgets in the Nord-West Region of Romania. The Annals of the University of Oradea. Economic Sciences, 1, pp. 931-941. At <http://steconomiceuoradea.ro/anale/ volume/2013/n1/098.pdf>, accessed 4 July 2019.

Piotrowski, S. J. and Van Ryzin, G. G. (2007). Citizen attitudes Toward transparency in local government. American Review of Public Administration, 37(3), pp. 306-323.

Sedmihradská, L. (2015). Budget Transparency in Czech Local Government. Procedia Economics and Finance, 25, pp. 598-606.

Serrano-Cinca, C., Rueda-Tomás, M. and Portillo-Tarragona, P. (2009). Factors Influencing E-Disclosure in Local Public Administrations. Environment and Planning C: Government and Policy, 27(2), pp. 355-378.

Stanić, B. (2018). Determinants of subnational budget/fiscal transparency: a review of empirical evidence. Public Sector Economics, 42(4), pp. 449-486. 
State Electoral Commission (2018) Izbori 2013: Konačni službeni rezultati za lokalne izbore. State Election Commission, Zagreb. At <http://www.izbori. hr/2013Lokalni/rezult/krug-1/rezultati.html>, accessed 15 May 2019.

Statistical office of the Republic of Slovenia (2019). Population data. At <https:// www.stat.si/StatWeb/en/Field/Index/17>, accessed 10 June 2019.

Styles, A. K. and Tennyson, M. (2007). The accessibility of financial reporting of $U$. S. municipalities on the internet. Journal of Public Budgeting, Accounting \& Financial Management, 19(1), pp. 56-92.

Suchman, M. C. (1995). Managing legitimacy: strategic and institutional approaches. Academy of Management Review, 20(3), pp. 571-610.

Tavares, A. F. and da Cruz, N. F. (2014). The determinants of local government transparency: a preliminary analysis. Proceedings of the $8^{\text {th }}$ International Conference on Theory and Practice of Electronic Governance, pp. 117-123. At <https://dl.acm.org/citation.cfm?id=2691291>, accessed 16 June 2019.

Wehner, J. and de Renzio, P. (2013). Citizens, legislators, and executive disclosure: the political determinants of fiscal transparency. World Development, 41(1), pp. 96-108.

Wong, W. and Welch, E. W. (2004). Does E-government promote accountability? a comparative analysis of website openness and government accountability. Governance, 17(2), pp. 275-297.

Zimmerman, J. L. (1977). The municipal accounting maze: an analysis of political incentives. Journal of Accounting Research, 15, pp. 107-144. 